\title{
An In-Depth Examination of the Philip Equation for Cataloging Infiltration Char- acteristics in Rangeland Environments
}

RICHARD A. JAYNES AND GERALD F. GIFFORD

\begin{abstract}
The objective of this study was to investigate the use of Philip's equation coefficients (which have, in theory, direct physical meaning) to characterize infiltration on rangelands. It was found that a least squares regression approach to estimating Philip equation parameters ( $S$ and $A$ ) essentially reduces $A$, and perhaps $S$, to empirical coefficients. However, the Philip equation does provide a model that fits infiltrometer data reasonably well and reflects significant differences between infiltration curves. The effects of land management and temporal variables (e.g., soil moisture, season) may be associated with changes in $S$ and $A$ for particular sites. Indexing of infiltration curves by model coefficients allows for infiltrometer data from different researchers to be pooled and provides a basis for simulation modeling of infiltration and runoff on small watersheds. Coefficients are tabulated for a variety of rangeland plant communities for easy reference by practicing rangeland hydrologists. Researchers who present infiltration data in the future are urged to represent their data, at least in part, in the form of $S$ and $A$ coefficients to expand results tabulated from this study.
\end{abstract}

Authors are graduate research assistant and professor, respectively, Watershed Science Unit, College of Natural Resources, Utah State University, Logan. Mr. Jaynes is currently attending law school at the University of Utah.

This work was supported jointly by the Utah Agricultural Experiment Station (Proj. 749) and the United States Department of the Interior, Office of Water Research and Technology, Project No. E-143-Utah, Agreement No. 14-34-0001-7193, as authorized under the Water Resources Research Act of 1964, as amended. Technical paper No. 2483, Utah Agricultural Experiment Station, Logan, 84322. Thanks are due Dr. Will Blackburn, Texas A\&M University, for use of data relative to Nevada plant communitics.

Manuscript received November 14, 1979.
Water movement through the soil-air interface (or infiltration) may be regarded as one of the most important processes on rangeland watersheds. Indeed, in an environment where convective rainstorms produce the majority of watershed runoff and erosion events, infiltration characteristics are key factors in determining the extent of soil loss, gully formation, and stream sedimentation. Since soil moisture on rangelands is often the most limiting resource for plant growth, the occurrence of surface runoff inhibits storm precipitation from promoting on-site forage production. In many instances, the main goal of rangeland watershed management is to simply prevent overland flow. Therefore, the variability in infiltration characteristics among plant communities and as a consequence of land management becomes an important item of study.

The ability to understand and predict infiltration characteristics and runoff events on rangeland watersheds (where extensive rainfall-runoff data rarely exists) is of great value to watershed hydrologists. There exists a variety of empirical techniques which are intended to simulate individual processes as well as the overall infiltration phenomenon. The development of infiltration models based on physically meaningful quantitative theories may well provide rangeland hydrologists with infiltration and runoff indexes which are more interpretable. Such models present the opportunity of utilizing infiltration characteristics of individual plant communities to predict watershed runoff events.

The two major objectives of this study were: (1) to investigate utilizing the well-known Philip infiltration model to index infiltration characteristics of rangeland communities (i.e., spatial variability both within and among different soil-plant complexes), and (2) 
to determine what magnitude of change (- or + ) must be expe:rienced in equation coefficients before temporal changes affecting community infiltration characteristics are deemed significant (e.g., the effects of land management, season, and antecedent soil moisture).

\section{The Philip Equation:}

Philip's infiltration equation is:

$$
I(t)=S t^{1 / 2}+A T
$$

where: $I(t)$ is cumulative infiltration at a given time $(t)(\mathrm{cm}), S$ is sorptivity $\left(\mathrm{cm} / \mathrm{hr}^{1 / 2}\right)$, and $A$ is a permeability coefficient or gravity term $(\mathrm{cm} / \mathrm{hr})$. Chapter 7 of Kirkham and Powers (1972) contains a detailed analysis of the mathematics of the Philip equation.

The first term of equation (1) describes the uptake of water by porous media via capillary forces and dominates infiltration when time is small (Philip 1957a, b). This term contains a coefficient $S$, or sorptivity $\left(\mathrm{cm} / \mathrm{hr}^{1 / 2}\right)$, which bears resemblance to the terms "permeability," "capillary conductivity," and "absorptivity." The term "sorptivity" is preferred by Philip (1957b) because it embraces both the concepts of absorption and desorption (i.e., the ability of the soil pores to absorb and release water by capillarity). Sorptivity may also be discussed in terms of pore-liquid geometry (Philip 1957b). Although the sorptivity parameter is not a directly measurable soil attribute, it may be derived from actual soil properties (Hanks and Ashcroft 1976).

The differential form of equation (1) is:

$$
i=1 / 2 S t^{-1 / 2}+A
$$

It is apparent from equation (2) that as time proceeds, the second term $A$, which describes the ability of the soil to transmit water due to gravity forces, plays an increasingly important role as a driving force (i.e., as $t$ approaches infinity, the first term approaches zero and $i$ approaches $A$ assymptotically). It follows that $A$ should be equivalent to the saturated hydraulic conductivity, $K_{\mathrm{w}}$, but this is not so. Since experimentally derived values of $A$ are not numerically equivalent to $K_{\mathrm{w}}$ values, the equation fails at large values of time. Also, since most soils are layered and violate the assumption of homogeniety, the value of $\boldsymbol{A}$ may be expected to change with time whereas $K_{\mathrm{w}}$ is always constant. However, in some cases, it is possible to semiempirically correlate $K_{\mathrm{w}}$ with $A$ (i.e., $A=K_{\mathrm{w}} / n$, where $n$ varies between 0.3 and 0.7 depending on time of infiltration and initial moisture content) (Philip 1969).

Philip (1957a) pointed out that both $S$ and $A$ coefficients vary with initial soil moisture content, $\theta_{\mathrm{n}}$. The parameter $S$ may be expected to continuously decrease as $\theta_{\mathrm{n}}$ increases. The $A$ term may be expected to be somewhat constant over a wide range of initial soil moistures (i.e., the lower range) but is found to increase continuously with increases in $\theta_{\mathrm{n}}$. The net effect of $S$ and $A$ response to different soil moistures is expressed in the concept that the infiltration characteristics of soil may be represented by a family of curves describing the progression of infiltration with time, where each curve represents an initial soil moisture condition. Infiltration rate shows a marked dependence on $\theta_{\mathrm{n}}$ at small times. As time proceeds, however, the infiltration curves for different initial soil moistures of the same soil approach an assymtote that should approximate $K_{\mathrm{w}}$ (Philip 1957c). Philip (1957b) concluded that equation (1) represents a very simple infiltration model, with physically interpretable parameters that are derived from a solution to the general flow equation, which should be useful in hydrologic studies (except for very large times).

Due to the complex array of factors governing infiltration, studies intended to correlate $S$ and $A$ with normally measured site variables have largely been unsuccessful. Fitzgerald et al. (1971) found that bulk density is the most important single factor explaining variability of $S$ and $A\left(R^{2}=0.33\right.$ and 0.43 , respectively). Organic matter, silt, clay, and macroporosity were also studied but single and multiple correlation accounted for little variability in the dependent variables. Gifford (1978) studied the effects of rangeland soil and vegetation properties on $S$ and $A$ values obtained by least squares regression. He found that the statistically significant regression equations for $S$ (containing \% soil less than $2 \mathrm{~mm}$ in diameter, bulk density, and $\left.(\% \text { crown cover })^{2}\right)$ and $A$ (with $\%$ soil less than $2 \mathrm{~mm}, \%$ silt plus clay, and bulk density) had $R^{2}$ values of 0.87 and 0.66 , respectively. He concluded that Philip equation parameters are more closely associated with soil factors than vegetation factors. Nnaji et al. (1975) also found strong correlations with near surface soil properties in Arizona.

In summary, the Philip equation is considered to have potential for use under rangeland conditions because its parameters may serve as physically interpretable indexes of infiltration characteristics, and the calculation of equation coefficients is easily made from available infiltrometer data. It should be noted that rangeland conditions do not satisfy most of the assumed criteria for the theory of transient flow in porous media. However, since infiltrometer studies can be used to simulate the short-duration, highintensity storms which dominate many rangeland areas (i.e., time is small enough that $S$ has a significant influence throughout the time of infiltration run, which is usually approximately 30 minutes), the Philip equation may be an adequate index within a 30 -minute time limit.

\section{Methods and Procedures}

Infiltrometer data for this study were collected by previous researchers. The data cover a number of rangeland plant communities on a variety of sites during various seasons, and even over a period of years within the same community. In collecting the data, unless otherwisc specified, a Rocky Mountain infiltrometer (Dortignac 1951) was utilized to simulate high intensity (usually 7.5 $\mathrm{cm} / \mathrm{hr}$ or greater) rainfall on plots a pproximately $0.23 \mathrm{~m}^{2}$ in area. Runoff was measured at selected time intervals during each infiltrometer run. Infiltration, as used here, includes water absorbed into the soil, that intercepted by vegetation, that held in depressions, and that in transit across the surface at the moment runoff was sampled. For all infiltration studies, water entry into the soil was expressed as a per-hour rate for each sampling time interval.

\section{Brief Description of Data Sources}

\section{Australian Rangeland Communities}

Gifford (1979a) gave a brief description of the plant communities located near Alice Springs, Northern Territory, Australia, for which infiltrometer data were collected. On each of the plant communities, infiltrometer studies were carried out for dry and wet moisture conditions and, except for bluebush, for scalped (surface $0.5 \mathrm{~cm}$ of soil was removed) and unscalped conditions. Mulgaperennial (Acacia aneura-perennial grasses), mulga-shortgrass (annual grasses), and gilgai communities were sampled both in September and November of 1973, whereas other communities were sampled only in September. Separate sampling schemes were carried out for the mulga-perennial-grove vs. intergrove and gilgai-interspace vs. depression situations. The effects of good and poor range condition, a result of grazing, were studied in the bluebush (Kochia astrotricha) type (good range condition was associated with a friable sandy loam surface soil; poor condition had a hard loam surface).

\section{Nevada Rangeland Communities}

Blackburn (1973) studied infiltration in native (i.e., without disturbance other than grazing) and treated plant communities. Study sites were located in several watersheds in Nevada. Infiltration studies were conducted at two water application rates ( 7.5 and $3.8 \mathrm{~cm} / \mathrm{hr}$ ) and for conditions of wet and dry antecedent moisture. Soil surface textures were variable but limiting horizons (i.e., argillic horizon, duripan, or bedrock) were generally encountered within $30 \mathrm{~cm}$ of the surface. The infiltrometer used was the driptype described by Blackburn and Skau (1974).

Studies in Treated vs. Untreated Pinyon-Juniper Communities in Central and Southern Utah

Information from Williams et al. (1969), Gifford et al. (1970), and Williams (1969) describes treated (chained) and untreated 
pinyon-juniper woodlands near Blanding, Eureka, Milford, and Price, Utah. Infiltrometer studies were carried out on several study sites to determine the impacts of disturbance. All plots were prewet to field capacity.

\section{A Comparison of Treatment Effects in the Big Sagebrush Type, Eastgate Basin, Nevada}

Gifford and Skau (1967) and Gifford (1968) reported the results of infiltrometer studies (plot size $5.7 \mathrm{~m}^{2}$ ) conducted in the sagebrush type on two sites in Eastgate Basin, near Reno, Nevada. Both wet and dry plot conditions were studied for the following six treatments: control, plowed and drill-seeded, ripped and drilled, herbicide sprayed and drill-seeded, and herbicide sprayed and contour deep furrow drilled. The two sites are designated "upper" (surface soils-crumb structure friable loam) and "lower" (soilsmassive, friable sandy loam).

\section{Study of a Plowed Big Sagebrush Site in Southern Utah}

Gifford and Busby (1974) described a sagebrush stand ncar Holbrook, Idaho, that was plowed and seeded to crested wheatgrass in July of 1968. Infiltrometer studies have been conducted since the time of treatment to detect subsequent infiltration behavior (Gifford 1977). The gently sloping study areas has a silty loam surface soil texture. Infiltration studies were conducted only on prewet plots.

\section{Infiltration Characteristics on Mining Sites in Utah}

Burton (1976) and Thompson (1977) collected infiltration rate data from a variety of mined sites throughout Utah. All sampling was accomplished during the summers of 1975 and 1976 with soils that were initially dry. The infiltrometer used in this study was a drip-type model after Meeuwig (1971) and briefly described by Malekuti and Gifford (1977).

\section{Calculation of Sorptivity (S) and Gravity Term (A) Parameters}

Approximations for values of $S\left(\mathrm{~cm} / \mathrm{hr}^{1 / 2}\right)$ and $A(\mathrm{~cm} / \mathrm{hr})$ were obtained by fitting equation (2) to each infiltrometer plot's data by least squares regression. Equation (2) may be written in the following manner,

$$
i=S\left(1 / 2 t^{-1 / 2}\right)+A
$$

which takes on the form of a simple linear model: $y=b x+a$. In this form the Philip equation plots as a straight line with slope of $S$ and intercept, as $t=\infty$, of $A$ (Fig. 1). Regressions were made for each individual study plot to allow better estimation of within-site variability of $S$ and $A$. Although rangeland soils often have very high initial infiltration rates, infiltration is generally defined after five minutes of simulated high intensity rain. Study plots which had less than three "defined" data points were not used in the analysis.

The length of most individual infiltration runs is fairly short: 25 to 30 minutes. However, Figure 2 illustrates that this time band is extremely important since it lies within a lower section of the rapidly changing portion of the sorptivity function.

\section{Discussion of Results from Preliminary Studies}

It is of interest to know just how much information is lost by reducing an entire infiltration curve, which generally is made up of 3 to 15 sampling points, to two ( $S$ and $A$ ) coefficients. Using coefficient of determination $\left(R^{2}\right)$ as a criterion, a pproximately $72 \%$ and $14 \%$ of the total 2,090 plots had coefficients of determination $\left(R^{2}\right)$ values greater than 0.75 and greater than 0.50 but less than 0.75 , respectively. Slightly over $14 \%$ of the plots had $R^{2}$ values of less than 0.50 . However, the plots with extremely low $R$-square values $(4.4 \%$ of the plots had $R$-squares less than 0.10$)$ resulted from a lack of variability in infiltration rates and not from a poor

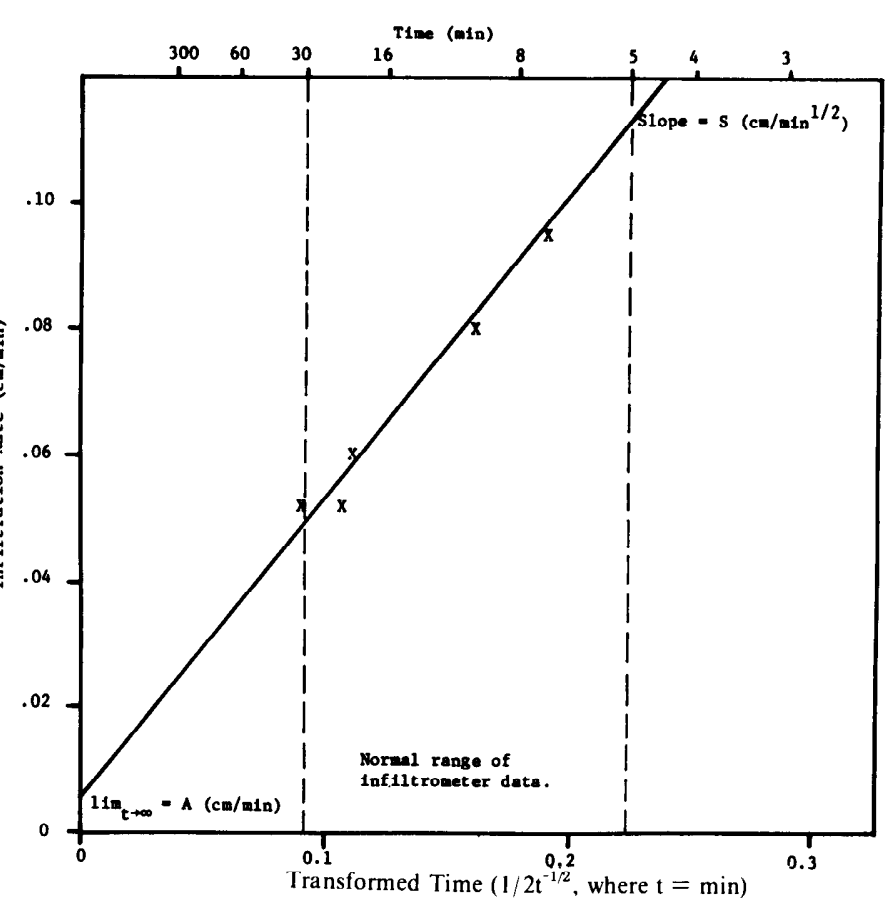

Fig. 1. Estimation of $S$ and $A$ by least squares regression. $X=$ data from infiltrometer run.

fit of the model (i.e., when $S$ was near zero, infiltration rates were defined mostly by the constant $A$ ). Low $R^{2}$ values on many other plots were observed to be a result of unexplainable behavior of the infiltrometer data and insufficient flexibility of the model. The information given in Table 1 indicates that the Philip equation fit the various data sources somewhat differently. The coefficient of determination, therefore, provides an index to, but not a complete picture of, how well the Philip equation fit rangeland infiltrometer data.

It has been previously stated that the value of $A$ should bear some relation to $K_{\mathrm{w}}$ (hydraulic conductivity). However, the regression procedures used in this study often produced negative values for $\boldsymbol{A}$. Reexamination of Figure 1 reveals how negative values of $\boldsymbol{A}$ are derived. That is, if the slope of the line, fit to the data points from the 5 to 30-minute time band, were to be made steeper, then $A$, defined as the $y$-axis intercept, might unavoidably be calculated as a negative value. Although it is known that the Philip equation fails at large values of time, the unusual values of $A$ calculated on some rangeland soils demand closer attention. Negative $A$ values could have been avoided using a variety of techniques, but we did not feel that constraining $A$ to only positive values was warranted in this study.

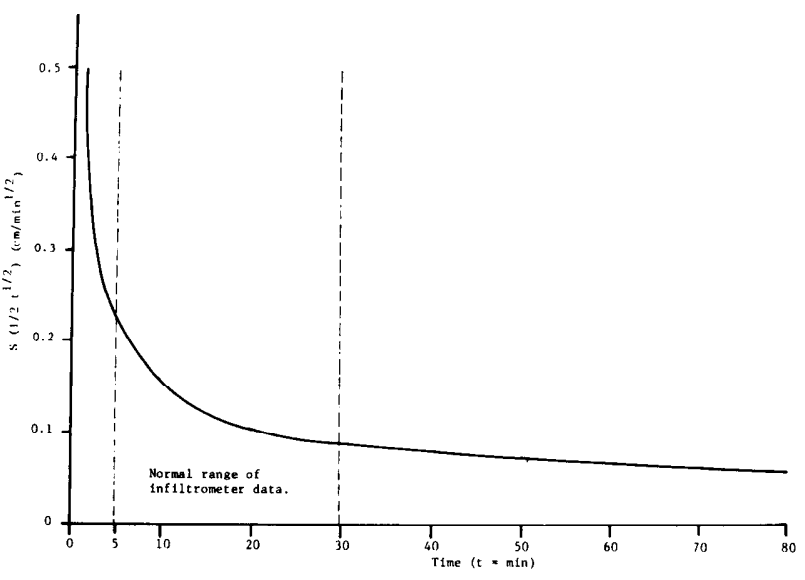

Fig. 2. Relationship of the sorptivity function to time, where $S=1$ $\mathrm{cm} / \mathrm{min}^{1 / 2}$. 
Table 1. Summary of Philip equation least squares regressions.

\begin{tabular}{lcccc}
\hline \hline & & & & \\
Data source & $\mathrm{n}$ & $\begin{array}{c}\text { Median } \\
R^{2}\end{array}$ & $\begin{array}{c}\text { Mean } \\
R^{2}\end{array}$ & $\begin{array}{c}\text { Standard } \\
\text { deviation } \\
\left(R^{2} \text { units }\right)\end{array}$ \\
\hline 1. Australia & 412 & .93 & .87 & .16 \\
2. Nevada & 394 & .98 & .94 & .13 \\
3. P-J chaining & 576 & .63 & .56 & .29 \\
4. Sagebrush (Nev.) & 92 & .92 & .90 & .08 \\
5. Sagebrush (Ida.) & 354 & .80 & .71 & .27 \\
6. Mining sites & 262 & .96 & .91 & .14 \\
\hline
\end{tabular}

Since it is impossible to both physically and practically interpret a negative long-term infiltration rate (a negativc $A$ would mean that at some point in time the value of the expression $S\left(1 / 2 t^{1 / 2}\right)+A$ would be less than 0 , which would suggest that the ground exudes water, or the opposite of infiltration occurs), the question is raised: What is the utility of an index with nonsensical values? This question becomes particularly critical since the advantage of the Philip equation lies in the physical interpretability of both $S$ and $A$. The lowest physically meaningful value that could exist for $A$ is zero. Were infiltration data to exist well beyond 30 minutes, (i.e., at 2 or 3 hours), it is unlikely that negative values of $A$ would occur. The fact that $A$ is negative if taken at $t=\infty$ does not mean that unusual values for predicted infiltration rates result at 30 minutes (Fig. 3). Each set of $S$ and $A$ values calculated in this study, regardless of magnitude, produce a positive and reasonable $30-$ minute infiltration rate. The empirical relationship that $A$ might bear with $K_{\mathrm{w}}$ is not intuitively apparent from the values derived. The value of $A$, theretore, becomes an index of the 30-minute value of $A$ (which is defined as the intercept of the vertical axis at 30 minutes in Figure 1) and will be retained for use in conjunction with its $S$ counterpart.

Another matter to consider pertains to the calculation of sorptivity or $S$. According to the Philip model, the value of the sorptivity poriton of the equation, $1 / 2 S t^{-1 / 2}$, decreases almost five-fold (i.e., from $1.0 S$ to $0.22 S$ ) in the first five minutes. This suggests that the best estimations of $S$ may be made when time is less than 5 minutes (i.e., before the gravity term, $A$, exerts significant influence). The value of the sorptivity portion of the equation only decreases by about half (i.e., $0.22 S$ to $0.09 S$ ) between 5 minutes and 30 minutes. This matter is further complicated by the absence of defined infiltration rates prior to 10 minutes on a number of infiltrometer plots.

A sensitivity study was conducted to answer the following two pertinent questions: (1) How are $S$ and $A$ calculations affected by missing (i.e., undefined or unsampled) data prior to 15 minutes and

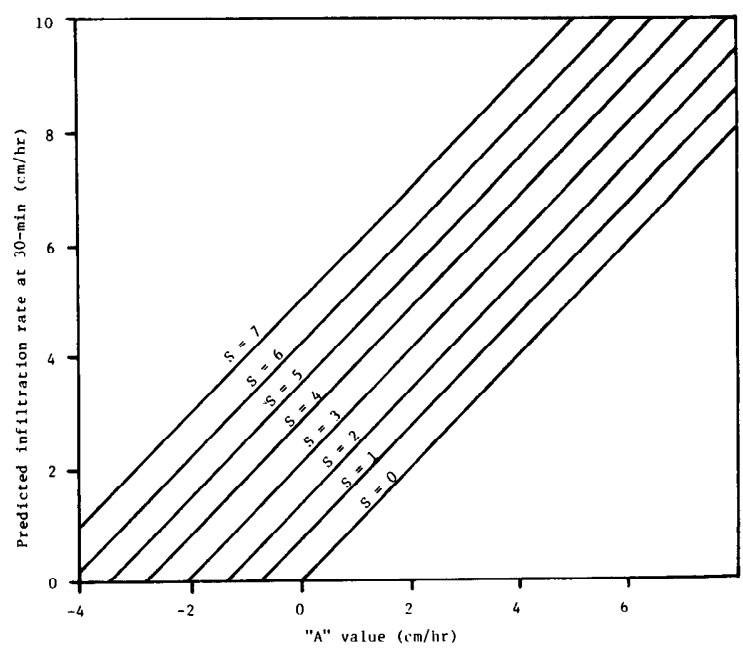

Fig. 3. Predicted 30-minute infiltration rates for various $S$ and $A$ combinations. later than 30 minutes?, and (2) How comparable are the $S$ and $A$ values obtained by analyzing data obtained from various sampling schemes?

The following procedure was employed in order to answer the first question.

1. Representative $S$ and $A$ values were selected. Selected values were $(S, A):(1,2),(2,2),(4,-1),(4,2)$.

2. Infiltration curves for those values were calculated and plotted.

3. Infiltration rates were scaled off graphed infiltration curves for the following minute time increments: $1,2,3,4,5,6,7,8$, $10,13,15,16,18,19,20,22,23,25,28,30,33,35,38,40,43$, $45,50,55,60$. (This process introduced ca. $1-5 \%$ random error into the data points).

4. Values for $S$ and $A$ were then calculated for each full set of infiltration rates as well as for incomplete sets of values.

Results indicate that early time intervals are more important in defining accurate $S$ and $A$ values than later time increments. However, even when both early and late intervals are absent, the amount of error introduced by calculating $S$ and $A$ from very limited data is rather small. Of course, this assumes very little experimental error or random variability of data points.

The second question regarding $S$ and $A$ sensitivity to various sampling schemes was approached in a similar manner. Seven representative $S$ and $A$ sets were selected and new $S$ and $A$ values were calculated based on the various sampling methods used by various researchers. Results indicate that $S$ and $A$ values computed by any one of the methods (i.e., when experimental error is not a factor) are highly comparable to $S$ and $A$ values computed from a full data set. This does not mean, however, that it is not desirable to have intensively sampled infiltration data. Random error due to plot heterogeniety and sampling technique could conceivably produce large errors in $S$ and $\boldsymbol{A}$ estimations, especially where only a few data points are available.

One is led to the conclusion that it is extremely doubtful that $A$ values, calculated by regression for rangeland infiltrometer plots, would compare directly or even semiempirically to laboratoryanalyzed values of hydraulic conductivity. Conversely, both of the sensitivity studies conducted suggest that estimated values for sorptivity should be fairly accurate. Unfortunatcly, data are not available to determine the amount of error introduced by estimating sorptivity by regression. Therefore, although $A$ and, perhaps, $S$ are empirical values, relative variability of $S$ and $A$ may take on meaningful interpretations if viewcd in light of the infiltration curves they produce. A decrease in the value of $S$, holding $A$ constant, would decrease the slope of the "die off" or initial portion of the curve. On the other hand, if $S$ were held constant, a decrease in $A$ would lower the entire infiltration curve by the magnitude of that decrease. Variability in $S$ and $A$ may be considered to reflect the net effect of the many forces affecting infiltration. This suggests a workable framework whereby infiltration curves and changes thereof might be adcquatcly indexed. However, direct physical interpretation of equation parameters appears to be limited due to the curve-fitting approach to $S$ and $A$ parameter estimation taken in this study.

\section{Data Analysis}

Factorial analyses of variance for both $S$ and $A$ (generally for unbalanced experimental design) were carried out where possible. That is, when qualitative levels of different factors (e.g., moisture, treatment, time of year, topography, range condition) were available for several study sites, a factorial approach was used. Otherwise, basic analysis of variance procedures were used. Where significant $F$ ratios for main effects or interactions were encountered, the multiple range statistic Least Significant Difference $(L S D)$ was utilized to ascertain significant changes in $S$ and $A$.

\section{Results and Discussion}

The number of observations means and standard deviations of $S$ 
Table 3. Philip equation coefficients for Nevada rangeland communities with an application rate of $7.5 \mathrm{~cm} / \mathrm{hr}$ for a $30-\mathrm{minute}$ duration.

\begin{tabular}{|c|c|c|c|c|c|c|c|}
\hline \multirow[b]{2}{*}{ Community } & \multirow{2}{*}{\multicolumn{2}{|c|}{ Number of observation: }} & \multicolumn{2}{|c|}{$\mathrm{S}\left(\mathrm{cm} / \mathrm{hr}^{1 / 2}\right)$} & \multicolumn{2}{|c|}{$\mathrm{A}(\mathrm{cm} / \mathrm{hr})$} & \multirow[b]{2}{*}{$\mathrm{I}(\mathrm{CM}$} \\
\hline & & & Mean & Std. dev. & Mean & Std. dev. & \\
\hline Low sage- & $\mathrm{D}^{1}$ & 18 & 2.96 & 1.35 & 2.89 & 2.03 & 3.53 \\
\hline $\begin{array}{l}\text { bluegrass } \\
\text { (LSB) }\end{array}$ & W & 21 & 1.74 & 1.05 & 2.70 & 2.66 & 2.58 \\
\hline Big sage- & $\mathrm{D}$ & 12 & 1.74 & 0.92 & 4.57 & 1.93 & 3.52 \\
\hline $\begin{array}{l}\text { wheatgrass } \\
\text { (SWB) }\end{array}$ & W & 15 & 1.43 & 1.00 & 3.99 & 2.54 & 3.01 \\
\hline Big sage- & $\mathrm{D}$ & 9 & 2.90 & 1.19 & 2.53 & 1.91 & 3.32 \\
\hline $\begin{array}{l}\text { bluegrass } \\
\text { (SBP) }\end{array}$ & W & 17 & 2.27 & 1.17 & 2.68 & 2.73 & 2.94 \\
\hline P-J low & D & 3 & 2.45 & 0.40 & 3.94 & 0.39 & 3.70 \\
\hline $\begin{array}{l}\text { sage } \\
\text { (PJS) }\end{array}$ & W & 6 & 2.49 & 0.31 & 2.95 & 0.89 & 3.24 \\
\hline Snowberry- & $\mathrm{D}$ & 4 & 0.85 & 0.30 & 6.21 & 0.52 & 3.71 \\
\hline $\begin{array}{l}\text { big sage } \\
\text { (SSW) }\end{array}$ & W & 6 & 1.23 & 0.45 & 5.16 & 0.54 & 3.45 \\
\hline Big- & $\mathrm{D}$ & 4 & 1.07 & 0.60 & 5.84 & 1.13 & 3.68 \\
\hline $\begin{array}{l}\text { sagebrush } \\
\text { (BSG) }\end{array}$ & $\mathrm{w}$ & 10 & 0.82 & 0.48 & 5.76 & 0.99 & 3.46 \\
\hline Crested & D & 3 & 1.77 & 0.62 & 5.00 & 0.91 & 3.75 \\
\hline $\begin{array}{l}\text { wheatgrass } \\
\text { (CWG) }\end{array}$ & W & 10 & 1.99 & 1.12 & 4.30 & 1.50 & 3.55 \\
\hline Pinyon- & D & 6 & 1.16 & 0.60 & 5.71 & 0.86 & 3.68 \\
\hline $\begin{array}{l}\text { juniper } \\
\text { (PUJ) }\end{array}$ & W & 6 & 2.12 & 1.13 & 2.95 & 2.05 & 2.97 \\
\hline Big sagc- & D & 18 & 2.56 & 1.43 & 3.55 & 1.92 & 3.59 \\
\hline $\begin{array}{l}\text { wheatgrass } \\
\text { (SCW) }\end{array}$ & w & 18 & 2.25 & 1.41 & 2.24 & 2.11 & 2.71 \\
\hline Utah & D & 5 & 2.97 & 2.00 & 2.48 & 2.87 & 3.34 \\
\hline $\begin{array}{l}\text { juniper } \\
\text { (UJP) }\end{array}$ & W & 4 & 1.98 & 1.39 & 2.16 & 3.35 & 2.48 \\
\hline Black sage & $\mathrm{D}$ & 11 & 1.55 & 0.88 & 5.10 & 1.83 & 3.65 \\
\hline $\begin{array}{l}\text { wheatgrass } \\
\text { (SIW) }\end{array}$ & W & 16 & 1.44 & 0.42 & 4.34 & 1.66 & 3.19 \\
\hline Juniper- & $\mathrm{D}$ & 16 & 2.02 & 1.28 & 4.45 & 2.15 & 3.65 \\
\hline $\begin{array}{l}\text { big sage } \\
\text { (JSS) }\end{array}$ & W & 18 & 1.28 & 0.71 & 4.01 & 2.40 & 2.91 \\
\hline Juniper- & $\mathrm{D}$ & 17 & 1.76 & 1.10 & 5.06 & 1.56 & 3.78 \\
\hline $\begin{array}{l}\text { wheatgrass } \\
\text { (JCW) }\end{array}$ & $\mathrm{W}$ & 7 & 1.36 & 0.81 & 3.73 & 2.84 & 2.83 \\
\hline
\end{tabular}

'Letter refers to antecedent soil moisture: $\mathrm{D}=\mathrm{dry}, \mathrm{W}=$ wet.

infiltration rate as a function of antecedent soil moisture.

Differences in the values of $S$ and $\boldsymbol{A}$ for study plots should reflect differences between infiltration curves for various communities and/or treatments. The results presented below may be assumed to be consistent with findings of the original researchers, except where otherwise indicated. Details beyond which can be presented in this paper are available in a project completion report by Jaynes and Gifford (1977).

\section{Australian Rangeland Communities}

An analysis of treatment effects based upon variations in $S$ and $A$ seems to yield results that are highly consistent with the data presented by Gifford (1979a). The original research was analyzed by either comparing mean infiltration rates at selected time intervals or by averaging all infiltration rates on a site for a given treatment combination. For example, the bluebush community exhibited extremely different $S$ and $A$ values for both wet and dry moisture conditions under different degrees of range condition (Fig. 4). Figure 5 shows that for the mulga-perennial, wet antecedent soil moisture conditions in the intergrove situation effects a decrease in $S$ and an increase in $A$. Soil moisture does not appear to cause much change in infiltration characteristics in the grove situations.

\section{Nevada Rangeland Communities}

As shown in Tables 3 and 4 , smaller values for both $S$ and $A$ were obtained from infiltrometer data collected with the lower intensity, longer duration simulated rainfall. The $A$ values were found to decrease for prewet plots, whereas $S$ values were apparently not significantly affected.

The results of analyzing infiltration characteristics in terms of $S$ and $A$ for rangeland communities in Nevada corresponds closely to the findings of Blackburn (1973). The data suggest that $S$ values for a community may be distinctive even when pooled over both moisture and application rate treatments. The value of $A$, however, was found to have a significant community-application rate interaction.

\section{Studies in Treated vs. Untreated Pinyon-Juniper Communities in Central and Southern Utah}

The effects of chaining in the pinyon-juniper type vary widely between locations. Most of the infiltration characteristics defined by Williams and Gifford (1969) indicate that significant effects due to mechanical disturbances are exceptional. Table 9 presents only the significantly affected $A$ values. In three cases the value of $A$ increased as a result of disturbance, whereas in two cases $A$ decreased. There were no significant treatment main effects or interactions determined for $S$.

\section{A Comparison of Treatment Effects in the Big Sagebrush Type, Eastgage Basin, Nevada}

The value of $S$ decreased significantly for conditions of wet antecedent soil moisture on both sites studied by Gifford (1968) although the magnitude of the decrease varied between sites. 
Table 4. Philip equation coefficients for Nevada rangeland communities with an application rate of $3.8 \mathrm{~cm} / \mathrm{hr}$ for a 60 -minute duration.

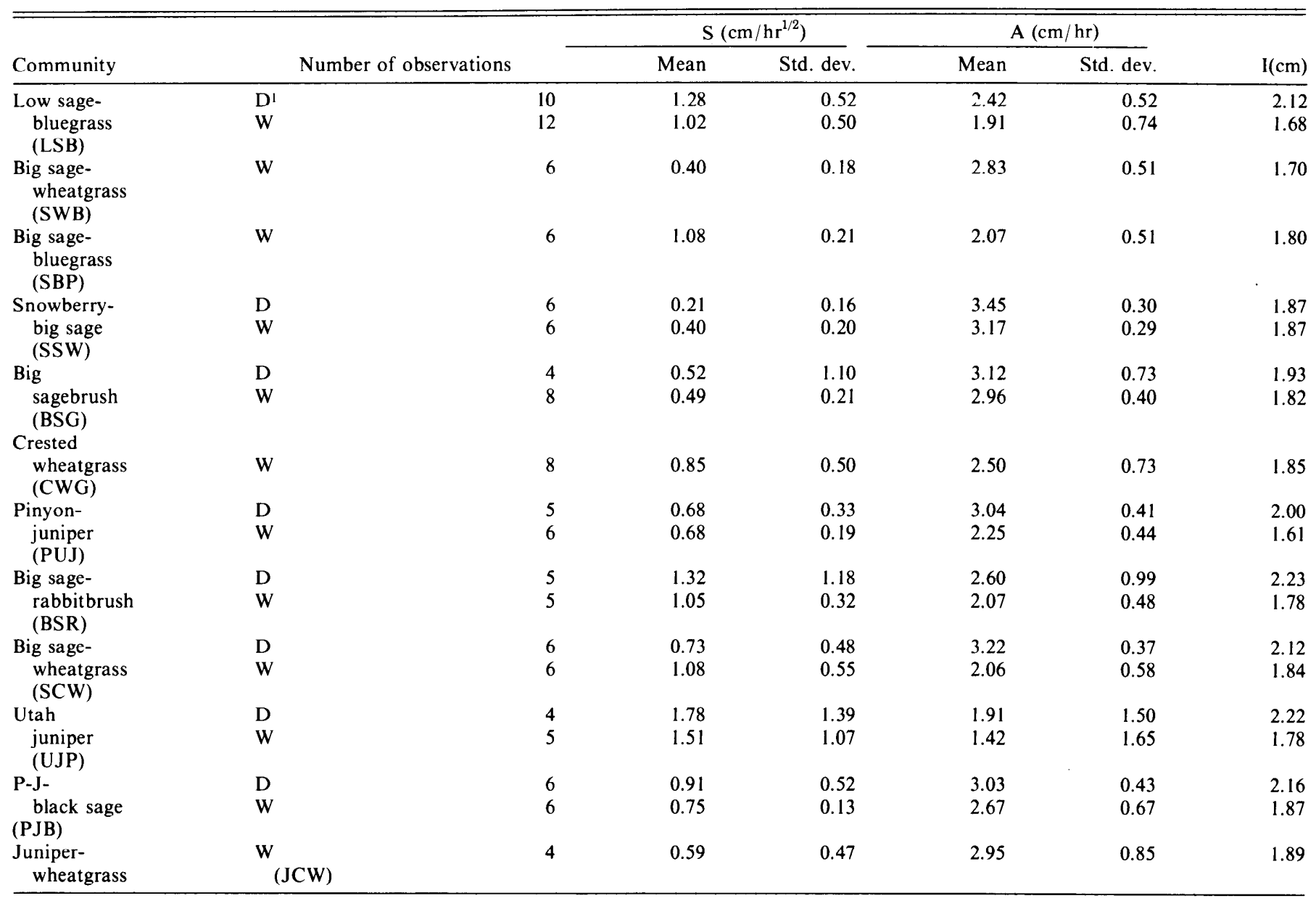

'Letter refers to antecedent soil moisture: $\mathrm{D}=\mathrm{dry}, \mathrm{W}=$ wet.

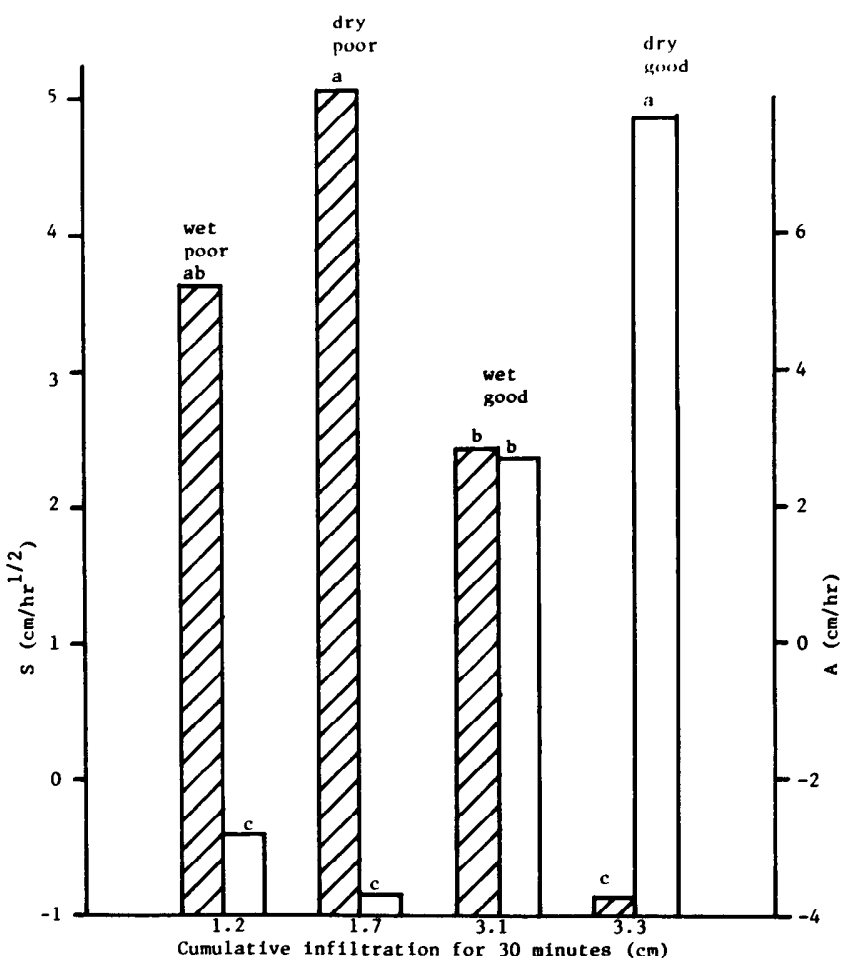

Fig.4. Australia rangeland communities bluebush factorial:moisturerange condition interaction. Shaded and unshaded bars represent $S$ and $A$ values, respectively. Similar bars that are matched with the same letter are not significantly different at the 0.10 level of probability.

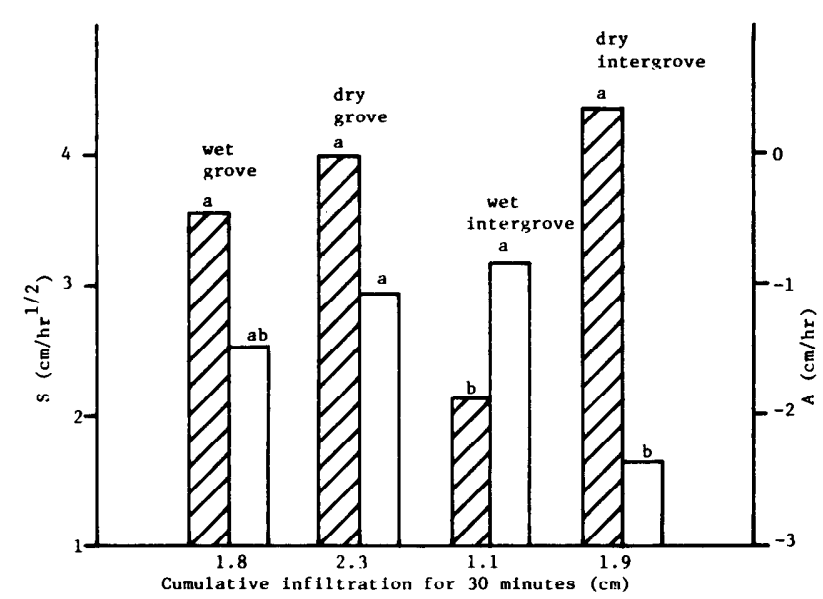

Fig. 5. Australia rangeland communities mulga-perennial groveintergrove factorial:moisture-vegetation pattern interaction. Shaded and unshaded bars represent $S$ and $A$ values, respectively. Bars matched with the same letter are not significantly different at the 0.10 level of probability. 
Table 5. Philip equation coefficients for the effects of disturbance on pinyon-juniper communities.

\begin{tabular}{|c|c|c|c|c|c|c|c|}
\hline \multirow[b]{2}{*}{ Location } & \multirow{2}{*}{\multicolumn{2}{|c|}{ Number of observations }} & \multicolumn{2}{|c|}{$\mathrm{S}\left(\mathrm{cm} / \mathrm{hr}{ }^{1 / 2}\right)$} & \multicolumn{2}{|c|}{$\mathrm{A}(\mathrm{cm} / \mathrm{hr})$} & \multirow[b]{2}{*}{$\mathrm{I}(\mathrm{cm})$} \\
\hline & & & Mean & Std. dev. & Mean & Std. dev. & \\
\hline \multicolumn{8}{|l|}{ Price, Utah } \\
\hline West Huntington & $U^{1}$ & 7 & 1.75 & 1.45 & 2.45 & 3.31 & 2.46 \\
\hline$(\mathrm{WHN})$ & D & 37 & 1.27 & 1.39 & 4.55 & 2.66 & 3.17 \\
\hline Pinnacle Bench & $\mathrm{U}$ & 6 & 0.41 & 1.00 & 2.85 & 1.68 & 1.72 \\
\hline (PNB) & $\mathrm{D}$ & 12 & 1.37 & 2.11 & 3.15 & 2.63 & 2.5 \\
\hline Horse Canyon & $\mathrm{U}$ & 5 & 1.43 & 0.32 & 1.44 & 1.16 & 1.73 \\
\hline$(\mathrm{HCN})$ & $\mathrm{D}$ & 7 & 0.95 & 0.44 & 2.45 & 0.91 & 1.90 \\
\hline Coal Creek & $\mathrm{U}$ & 6 & 1.30 & 1.13 & 4.10 & 2.23 & 2.97 \\
\hline$(\mathrm{CCK})$ & D & 13 & 2.15 & 2.24 & 3.44 & 2.90 & 3.24 \\
\hline $\begin{array}{l}\text { Wood Hill } \\
\text { (WDH) }\end{array}$ & $\mathrm{U}$ & 8 & 1.33 & 0.99 & 2.90 & 1.27 & 2.39 \\
\hline \multicolumn{8}{|l|}{ Eureka, Utah } \\
\hline Boulter & $\mathrm{U}$ & 6 & 0.57 & 0.86 & 3.35 & 1.32 & 2.08 \\
\hline (BLT) & $\mathrm{D}$ & 19 & 2.21 & 2.94 & 3.29 & 3.32 & 3.21 \\
\hline Loftgreen & $\mathrm{U}$ & 9 & 2.22 & 1.34 & 1.76 & 0.88 & 2.45 \\
\hline (LOF) & $\mathrm{D}$ & 16 & 1.45 & 1.96 & 4.94 & 3.20 & 3.50 \\
\hline Black Rk. Cny. & $\mathrm{U}$ & 4 & 1.29 & 1.28 & 2.74 & 1.49 & 2.28 \\
\hline (BRC) & $\mathrm{D}$ & 11 & 1.13 & 0.91 & 2.31 & 1.50 & 1.95 \\
\hline Onaqai & $\mathrm{U}$ & 4 & 1.99 & 0.78 & 1.45 & 0.71 & 2.13 \\
\hline (ONQ) & $\mathrm{D}$ & 8 & 2.71 & 1.36 & 2.27 & 2.37 & 3.05 \\
\hline Gvnt. Crk. \#1 & $\mathrm{U}$ & 4 & 1.10 & 0.73 & 1.25 & 0.57 & 1.34 \\
\hline$(\mathrm{GCA})$ & $\mathrm{D}$ & 8 & 2.45 & 0.99 & -1.58 & 1.04 & 0.94 \\
\hline Gvnt. Crk. \#2 & $\mathrm{U}$ & 3 & 1.49 & 1.09 & 1.00 & 1.85 & 1.55 \\
\hline (GCB) & $\mathrm{D}$ & 7 & 2.03 & 0.78 & -0.18 & 1.28 & 1.35 \\
\hline Gvnt. Crk. \#3 & $\mathrm{U}$ & 4 & 1.36 & 0.59 & 0.50 & 0.67 & 1.21 \\
\hline$(\mathrm{GCC})$ & $\mathrm{D}$ & 6 & 1.68 & 0.94 & 0.30 & 0.73 & 1.34 \\
\hline Gvnt. Crk. \#4 & $\mathrm{U}$ & 4 & 1.36 & 0.59 & 0.50 & 0.67 & 1.21 \\
\hline (GCD) & $\mathrm{D}$ & 7 & 2.09 & 1.56 & 2.39 & 1.98 & 2.67 \\
\hline $\begin{array}{l}\text { Gvnt. Crk. \#5 } \\
\text { (GCE) }\end{array}$ & $\mathrm{U}$ & 4 & 1.49 & 0.66 & 2.88 & 0.33 & 2.49 \\
\hline \multicolumn{8}{|l|}{ Blanding, Utah } \\
\hline Peters Pt. \#1 & $\mathrm{U}$ & 7 & 4.30 & 2.14 & 0.83 & 2.04 & 3.46 \\
\hline (PPA) & $\mathrm{D}$ & 18 & 2.75 & 1.62 & -0.01 & 1.55 & 1.94 \\
\hline Peters Pt. \#2 & $\mathrm{U}$ & 7 & 4.30 & 2.14 & 0.83 & 2.04 & 3.46 \\
\hline (PPB) & $\mathrm{D}$ & 7 & 3.74 & 1.68 & 1.33 & 1.82 & 3.31 \\
\hline Brush Basin & $\mathrm{U}$ & 9 & 3.00 & 1.41 & 1.09 & 1.17 & 2.67 \\
\hline (BRB) & $\mathrm{D}$ & 8 & 3.24 & 2.14 & 0.81 & 1.92 & 2.70 \\
\hline Alkali Ridge & $\mathrm{U}$ & 9 & 3.31 & 1.85 & 0.73 & 1.41 & 2.71 \\
\hline (prot.)(ARP) & $\mathrm{D}$ & 5 & 5.37 & 2.45 & 0.36 & 2.06 & 3.98 \\
\hline Alk. R. (no & $\mathrm{U}$ & 9 & 3.31 & 1.85 & 0.73 & 1.41 & 2.71 \\
\hline $\begin{array}{l}\text { protection) } \\
\text { (ARN) }\end{array}$ & $\mathrm{D}$ & 10 & 4.40 & 2.40 & 0.81 & 2.25 & 3.52 \\
\hline Job \#149 & $\mathrm{U}$ & 12 & 5.19 & 2.37 & 0.92 & 1.94 & 4.13 \\
\hline (JOB) & $\mathrm{D}$ & 7 & 4.19 & 2.57 & 1.42 & 1.99 & 3.67 \\
\hline \multicolumn{8}{|l|}{ Milford, Utah } \\
\hline Indian Peaks \#1 & $\mathrm{U}$ & 9 & 1.84 & 1.53 & 2.50 & 1.03 & 2.60 \\
\hline (IPA) & $\mathrm{D}$ & 7 & 1.56 & 1.74 & 3.38 & 3.02 & 2.79 \\
\hline Indian Peaks \#2 & $\mathrm{U}$ & 9 & 1.84 & 1.53 & 2.60 & 1.03 & 2.60 \\
\hline (IPB) & $\mathrm{D}$ & 15 & 2.17 & 1.61 & 1.73 & 2.79 & 2.40 \\
\hline Indian Peaks \#3 & $\mathrm{U}$ & 12 & 4.21 & 4.42 & 6.14 & 5.59 & 6.05 \\
\hline (IPC) & $\mathrm{D}$ & 12 & 4.97 & 12.77 & 5.80 & 8.77 & 6.41 \\
\hline Indian Peaks \#4 & $\mathrm{U}$ & 10 & 2.87 & 1.67 & 2.71 & 4.52 & 3.38 \\
\hline (IPD) & $\mathrm{D}$ & 11 & 4.98 & 3.60 & -0.90 & 4.59 & 3.07 \\
\hline New Árrowhead & $\mathrm{U}$ & 11 & 3.60 & 4.34 & 3.24 & 3.94 & 4.17 \\
\hline Mine (ARM) & $\mathrm{D}$ & 11 & 2.01 & 2.45 & 4.94 & 3.35 & 3.89 \\
\hline Jockeys & $\mathrm{U}$ & 12 & 2.27 & 0.91 & 1.00 & 1.08 & 2.11 \\
\hline$(\mathrm{JOC})$ & D & 10 & -1.03 & 7.65 & 7.48 & 8.18 & 3.01 \\
\hline USU Study Site & $\mathrm{U}$ & 13 & 1.60 & 2.37 & 4.12 & 2.91 & 3.19 \\
\hline$\# 1$ (DIP) & D & 9 & 3.19 & 1.56 & 2.01 & 3.32 & 3.26 \\
\hline USU Study Site & $\mathrm{U}$ & 13 & 1.60 & 2.37 & 4.12 & 2.91 & 3.19 \\
\hline$\# 2$ (WND) & D & 13 & 2.69 & 2.27 & 1.36 & 2.53 & 2.58 \\
\hline
\end{tabular}

'Letter refers to treatment: $\mathrm{U}=$ undistrubed, $\mathrm{D}=$ disturbed. 
Table 7. Philip equation coefficients for infiltration after plowing big sagebrush, Holbrook, Idaho.

\begin{tabular}{|c|c|c|c|c|c|c|}
\hline & \multirow{2}{*}{$\begin{array}{c}\text { Number } \\
\text { of } \\
\text { observa- } \\
\text { tions }\end{array}$} & \multicolumn{2}{|c|}{$\mathrm{S}\left(\mathrm{cm} / \mathrm{hr}^{1 / 2}\right)$} & \multicolumn{2}{|c|}{$\mathrm{A}(\mathrm{cm} / \mathrm{hr})$} & \multirow{2}{*}{$\mathrm{I}(\mathrm{cm}$} \\
\hline & & \multicolumn{2}{|c|}{ MeanStd. dev. } & \multicolumn{2}{|c|}{ MeanStd. dev. } & \\
\hline \multicolumn{7}{|l|}{ Control } \\
\hline $8-6-68$ & 22 & 3.37 & 1.70 & 2.67 & 2.76 & 3.72 \\
\hline \multicolumn{7}{|c|}{ After plowing } \\
\hline $4-12-69$ & 21 & 7.51 & 6.00 & 1.58 & 5.60 & 4.52 \\
\hline $6-18-69$ & 20 & 5.81 & 4.30 & 0.84 & 4.26 & 4.53 \\
\hline $8-11-69$ & 24 & 2.77 & 3.18 & 1.50 & 3.48 & 2.71 \\
\hline $6-20-70$ & 20 & 6.66 & 9.00 & -1.64 & 8.60 & 3.89 \\
\hline $8-27-70$ & 24 & 4.15 & 4.58 & 0.22 & 4.52 & .04 \\
\hline $10-3-70$ & 20 & 3.31 & 7.53 & 0.83 & 7.29 & 2.76 \\
\hline $5-21-71$ & 19 & 5.25 & 5.53 & -1.08 & 4.59 & 3.17 \\
\hline 8-16-71 & 20 & 5.50 & 3.34 & -1.78 & 3.35 & 3.00 \\
\hline $9-20-71$ & 24 & 2.27 & 2.05 & 0.66 & 1.99 & 1.94 \\
\hline $5-29-72$ & 21 & 5.16 & 2.82 & -1.01 & 2.54 & 3.14 \\
\hline $7-25-72$ & 24 & 4.09 & 2.15 & -0.66 & 2.25 & 2.56 \\
\hline $9-11-72$ & 24 & 4.02 & 2.02 & -0.52 & 2.01 & 2.58 \\
\hline $6-4-75$ & 18 & 2.74 & 1.11 & 0.83 & 2.18 & 2.35 \\
\hline $8-20-75$ & 17 & 2.39 & 1.04 & 2.00 & 1.63 & 2.69 \\
\hline $5-16-76$ & 18 & 1.83 & 1.44 & 1.20 & 1.51 & 1.89 \\
\hline $9-15-76$ & 18 & 2.21 & 1.57 & 0.99 & 1.60 & 2.06 \\
\hline
\end{tabular}

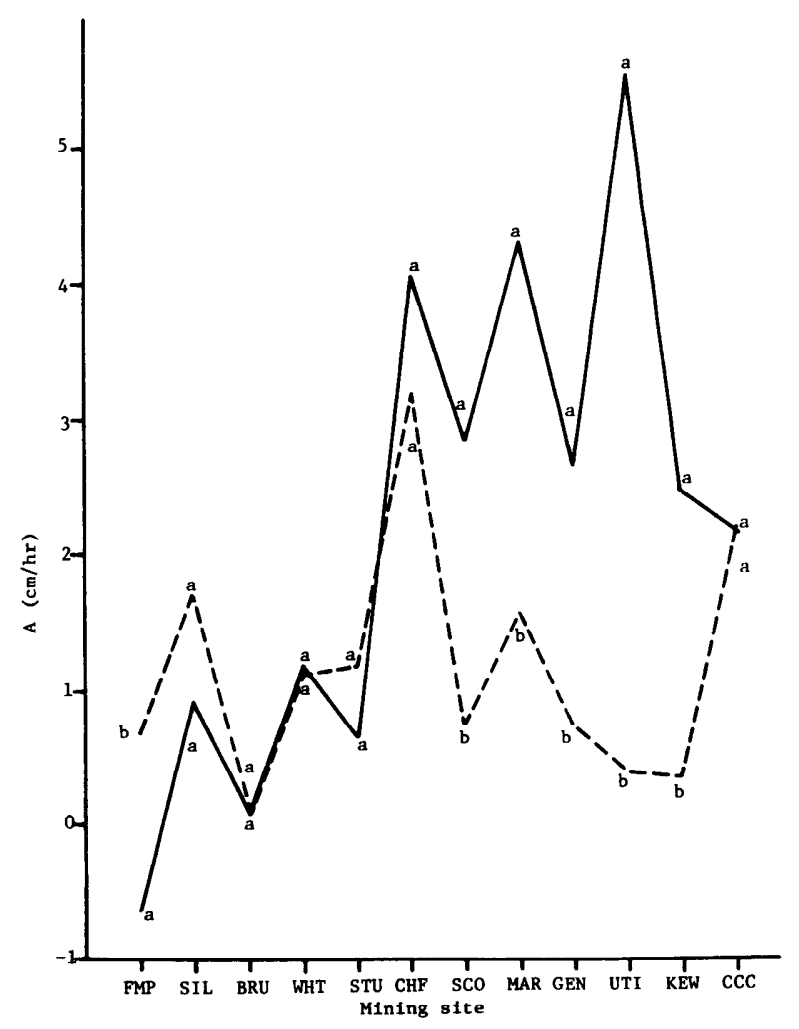

Fig. 8. Mining sites topography. site factorial:topography-mining site interactions for $A$. The dashed and solid lines represent relatively flat and sloped sites, respectively. Slope effects on the same site that are matched with the same letter are not significantly different at the 0.10 level of probability. See Table 8 for explanation of symbols.
Gifford (1968) observed that the cultural treatment effects were often located in the middle portion of the 30 -minute infiltration curve. It appears that the conversion of infiltration curves to $S$ and $A$ values decreases the sensitivity of the analysis to unusual "bumps" or "dips" in infiltration curves. Such phenomena are essentially ignored by the Philip equation. The $S$ and $A$ values for each treatment (pooled over soil moisture and both sites) were used to calculate cumulative infiltration for $\mathbf{3 0}$ minutes. The following ranking scheme of treatments was thus obtained (ranked from high to low):

1. Spray, drill

2. Rip, drill

3. Spray, contour deep furrow drill

4. Control

5. Plow, contour deep furrow drill

6. Plow, drill

A similar ranking by Gifford (1968) produced the same results with the exception that treatments 1 and 2 were reversed in order.

\section{Study of Plowed Big Sagebrush Site in Southern Idaho}

The response of a big sagebrush community to plowing and subsequent grazing (initiated in 1970) is illustrated in terms of $S$ and $A$ in Figure 6. Two important general trends are apparent: (1) $S$ values decrease and $A$ values increase from early to late season sampling dates within any year, and (2) infiltration rates (as indexed by the $I$ value) tend to decrease after the initial year following plowing treatment. These data illustrate how the infiltration characteristics for a given site may vary as a result of plowing treatment, season, and grazing (i.e., cattle were allowed to graze the area after $8 / 27 / 70$ ). It may be noted also that seasonal fluctuations in infiltration rates are minimized after the second year of grazing (i.e., grazing tends to reduce seasonal variability in infiltration rates).

\section{Infiltration Characteristics on Mining Sites in Utah}

A major purpose for the infiltrometer studies on mined sites in Utah was to arrive at a suitable scheme of hydrologic classification of spoils (Burton et al. 1978). The analysis of variance for infiltration data from mined sites indicated that even with means from only four replications, significant differences exist among $S$ and $A$ values. Both $S$ and $A$ exhibit a significant topography-mining site interaction (Fig. 7 and 8). It seems as though a classification scheme based upon the integrated infiltration curve predicted by a given $S$ and $A$ "set" would contain substantially more information than an infiltration-constant analysis.

\section{Conclusions}

Philip's solution to the general flow equation, as applied in this study, represents a feasible model for estimating small-plot infiltration characteristics in rangeland environments. However, least squares estimation of the two model coefficients, $S$ and $A$, from infiltrometer data precludes a direct physical interpretation of $A$. This curve-fitting approach to calculating $S$ and $A$ does provide relative indexes that have been shown to accurately reflect the characteristics of many rangeland infiltration curves.

This study has shown that the reduction of an infiltration curve to a two-term index simplifies data analysis and facilitates comparisons of data collected by different researchers. In addition to mimicking infiltration curves, a set of coefficients also provides a means whereby cumulative infiltration (i.e., the area under the curve of infiltration rate vs. time) may be easily calculated. This adds important information to the analysis of infiltrometer data.

Model coefficients are sensitive to both spatial and temporal factors (e.g., topography, soil moisture, site treatment, season, etc.) that influence infiltration. That is, a reexamintion of former infiltration studies in light of Philip equation coefficients has led to similar conclusions. The effect of factors such as antecedent soil moisture and season of sampling on $S$ and $A$ is öften significant but 
Table 8. Philip equation coefficients for mining sites in Utah.

\begin{tabular}{|c|c|c|c|c|c|c|c|c|c|c|c|c|c|}
\hline \multirow{2}{*}{$\begin{array}{l}\text { Location } \\
\text { Sampled in } 1975\end{array}$} & $\begin{array}{l}\text { Number } \\
\text { of } \\
\text { observa- } \\
\text { tions }\end{array}$ & \multicolumn{2}{|c|}{$\underline{\mathrm{S}\left(\mathrm{cm} / \mathrm{hr}^{1 / 2)}\right.}$} & \multicolumn{2}{|c|}{ A $(\mathrm{cm} / \mathrm{hr})$} & $\mathrm{I}(\mathrm{cm})$ & Location & $\begin{array}{c}\text { Number } \\
\text { of } \\
\text { observa- } \\
\text { tions }\end{array}$ & \multicolumn{2}{|c|}{$\mathrm{S}\left(\mathrm{cm} / \mathrm{hr}^{1 / 2}\right)$} & \multicolumn{2}{|c|}{$\mathrm{A}(\mathrm{cm} / \mathrm{hr})$} & $\mathrm{I}(\mathrm{cm})$ \\
\hline & & & & & & & & & & & & & \\
\hline Five Mile ${ }^{1}$ & 4 & 3.03 & 0.42 & -0.61 & 0.76 & 1.84 & $\begin{array}{l}\text { Castle Gate } \\
\text { (CAS) }\end{array}$ & & & & & & \\
\hline $\begin{array}{l}\text { Pass (FMP) FL } \\
\text { Lewiston Canyonon }\end{array}$ & $\begin{array}{l}4 \\
4\end{array}$ & $\begin{array}{l}1.71 \\
1.88\end{array}$ & $\begin{array}{l}1.01 \\
0.70\end{array}$ & $\begin{array}{l}0.69 \\
1.09\end{array}$ & $\begin{array}{l}0.66 \\
0.83\end{array}$ & $\begin{array}{l}1.55 \\
1.87\end{array}$ & $\begin{array}{l}\text { (CAS) } \\
\text { Stauffer, S.E. }\end{array}$ & 4 & 0.82 & 0.38 & 2.84 & 0.90 & 2.00 \\
\hline (LEW) TL & & & & & & & (STS) & 4 & 2.00 & 0.67 & 0.78 & 1.16 & 1.80 \\
\hline $\begin{array}{l}\text { Golden Gate } \\
\text { (GOL) FL }\end{array}$ & 4 & 3.29 & 0.19 & -0.27 & 0.27 & 2.16 & $\begin{array}{c}\text { SD } \\
\text { Stauffer, N.W. }\end{array}$ & 4 & 1.93 & 0.12 & 1.18 & 0.54 & 1.96 \\
\hline Silver City (SIL) & 4 & 1.14 & 0.64 & 0.91 & 1.08 & 1.26 & (STN) & 4 & 2.29 & 0.74 & 0.97 & 0.19 & 2.10 \\
\hline FL & 4 & 2.15 & 0.98 & 1.70 & 1.16 & 2.37 & SD & 4 & 1.71 & 0.47 & 1.25 & 0.22 & 1.83 \\
\hline Sunrise (SUN) & & & & & & & Sampled in 1976 & & & & & & \\
\hline $\begin{array}{c}\text { SD } \\
\text { Sport Mt }\end{array}$ & $\begin{array}{l}4 \\
3\end{array}$ & $\begin{array}{l}1.11 \\
1.79\end{array}$ & $\begin{array}{l}0.15 \\
0.30\end{array}$ & $\begin{array}{l}3.07 \\
2.00\end{array}$ & $\begin{array}{l}1.82 \\
1.10\end{array}$ & $\begin{array}{l}2.32 \\
2.27\end{array}$ & Five Mile Pass & & & & & & \\
\hline Brush (BRU) & 4 & 3.62 & 1.02 & 0.09 & 0.72 & 2.61 & $(\mathrm{FML})$ & 4 & 5.04 & 2.37 & -0.11 & 4.06 & 3.51 \\
\hline $\mathrm{FL}$ & 4 & 2.86 & 1.04 & 0.09 & 0.54 & 2.07 & Mercur (MCR) & 4 & 2.00 & 0.59 & 0.40 & 0.66 & $\begin{array}{l}1.61 \\
3.19\end{array}$ \\
\hline Keystone Wallace & & & & & & & $\begin{array}{c}\text { Chief \#l (CHF) } \\
\text { FL }\end{array}$ & $\begin{array}{l}3 \\
4\end{array}$ & 1.63 & $\begin{array}{l}0.38 \\
0.62\end{array}$ & $\begin{array}{l}4.08 \\
3.21\end{array}$ & 7 & $\begin{array}{l}3.19 \\
3.19\end{array}$ \\
\hline$(\mathrm{KYW})$ & 4 & 0.77 & 0.31 & 5.56 & 0.41 & 3.32 & Scofield (SCO) & $\begin{array}{l}4 \\
4\end{array}$ & $\begin{array}{l}2.24 \\
2.19\end{array}$ & $\begin{array}{l}0.62 \\
1.32\end{array}$ & $\begin{array}{l}3.21 \\
2.84\end{array}$ & $\begin{array}{l}0.79 \\
2.47\end{array}$ & $\begin{array}{l}3.19 \\
2.97\end{array}$ \\
\hline SD & 4 & 1.35 & 0.27 & 2.04 & 0.57 & 1.98 & FL & 4 & 2.74 & 0.56 & 0.75 & 0.99 & 2.31 \\
\hline $\begin{array}{l}\text { Old Hickory } \\
\text { (OLD) }\end{array}$ & 4 & 0 & 0.64 & 4.98 & 1.38 & 2.87 & $\begin{array}{l}\text { Joe's Vall } \\
\text { (JOE) }\end{array}$ & & & & & & \\
\hline Bowana (BOW) & 4 & 2.31 & 0.20 & 1.33 & 0.67 & 2.30 & $\begin{array}{l}\text { (JOE) } \\
\text { Henifer (HEN) }\end{array}$ & $\begin{array}{l}4 \\
4\end{array}$ & 0.65 & $\begin{array}{l}0.28 \\
0.96\end{array}$ & $\begin{array}{l}3.53 \\
1.79\end{array}$ & 0.54 & $\begin{array}{l}2.23 \\
2.54\end{array}$ \\
\hline Rattesnake & & & & & & & Rock Candy Mt. & & & 10 & 9 & 95 & 2 \\
\hline Ranch (RAT) & 3 & 1.63 & 1.63 & 4.73 & 1.53 & 3.52 & (RCM) & 4 & 2.17 & 0.86 & 2.69 & 1.72 & 2.88 \\
\hline $\begin{array}{l}\text { Fry Canyon } \\
\text { (FRY) }\end{array}$ & 4 & 1.97 & 0.21 & 1.12 & 0.87 & 1.95 & Marysvale & & & & & & \\
\hline White Canyon & & & & & & & FL & $\begin{array}{l}4 \\
4\end{array}$ & $\begin{array}{l}0.65 \\
1.13\end{array}$ & $\begin{array}{l}0.21 \\
0.51\end{array}$ & $\begin{array}{l}4.33 \\
1.58\end{array}$ & $\begin{array}{l}1.13 \\
0.64\end{array}$ & $\begin{array}{l}2.61 \\
1.59\end{array}$ \\
\hline (WHT) & $\begin{array}{l}4 \\
4\end{array}$ & $\begin{array}{l}2.50 \\
228\end{array}$ & $\begin{array}{l}1.12 \\
0.84\end{array}$ & 1.1 & $\begin{array}{l}0.56 \\
0.95\end{array}$ & $\begin{array}{l}2.36 \\
2.17\end{array}$ & Bullion Canyon & 4 & 0.79 & 0.20 & 3.56 & 0.82 & 2.34 \\
\hline $\begin{array}{c}\text { FL } \\
\text { Dutchman }\end{array}$ & & 2.28 & 0.8 & 1.1 & 0.9 & 2.17 & (BUL) & & & & & & \\
\hline (DUT) & 4 & 1.50 & 0.73 & 0.73 & 0.72 & 1.43 & $\begin{array}{l}\text { Milford (MIL) } \\
\text { King David }\end{array}$ & 4 & 1.21 & 0.22 & 3.97 & 0.88 & 2.84 \\
\hline $\begin{array}{l}\text { Alta, parking lot } \\
\text { (ALP) }\end{array}$ & 4 & 1.71 & 0.23 & 0.60 & 0.87 & & (KND) & 4 & 2.70 & 1.41 & 1.45 & 2.39 & 2.63 \\
\hline Alta, Upper & & & $0.2 J$ & 0.00 & 0.01 & 1.51 & Geneva (GEN) & 4 & 1 & 0.37 & 3.63 & 36 & 2.61 \\
\hline $\begin{array}{c}\text { Emma (ALU) } \\
\text { Alta Bel Vega }\end{array}$ & 4 & 3.99 & 1.08 & 1.80 & 1.31 & 3.72 & $\begin{array}{c}\text { FL } \\
\text { Upper Marysvale }\end{array}$ & 4 & 2.09 & 0.33 & 0.71 & 0.23 & 1.83 \\
\hline $\begin{array}{l}\text { AIta, Bel vega } \\
\text { (ALB) }\end{array}$ & 4 & 1.4 & 0. & & 1.4 & 2.2 & (UPM) & 3 & 0.98 & 0.14 & 1.64 & 0.18 & 1.51 \\
\hline Pacific (PAC) & 4 & 1. & & & & 2.01 & Firefly (FRF) & 4 & 0.95 & 0.56 & 3.99 & 0.93 & 2.67 \\
\hline TL & 4 & 0.91 & 0.53 & 3.33 & 2.27 & 2.31 & Queen & 4 & 170 & 189 & 358 & & \\
\hline $\begin{array}{c}\text { Stubbs Clay } \\
\text { (STU) }\end{array}$ & & & & & & & $\begin{array}{r}\text { (V } \\
\text { Natu }\end{array}$ & 4 & $1 . \%$ & 1.89 & 3.58 & 2.11 & 2. \\
\hline $\begin{array}{c}\text { (STU) } \\
\text { FL }\end{array}$ & $\begin{array}{l}4 \\
4\end{array}$ & $\begin{array}{l}1.67 \\
1.65\end{array}$ & & & & $\begin{array}{l}1.50 \\
1.76\end{array}$ & (NAT) & 4 & 2.35 & 1.23 & 1.48 & 1.01 & 2.40 \\
\hline Mill Creek (MLC) & 4 & 1.34 & 0.55 & 3.83 & 0.99 & 2.86 & Dog Valley & & & & & & \\
\hline Kimberly, SO. & & & & & & & $\begin{array}{l}\text { (DOG) } \\
\text { (D) }\end{array}$ & 5 & 1.1 & 0. & 3.5 & 0 & 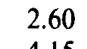 \\
\hline (KMS) & 3 & 2.18 & 0.66 & 3.1 & 1.2 & 3.10 & Utah Int'1 (UTI) & 4 & 1. & & & & 4.1 \\
\hline (K & $\lambda$ & & & & & 3. & $\begin{array}{l}\mathrm{FL} \\
\mathrm{SD}\end{array}$ & 4 & & & 0.39 & & 1.98 \\
\hline Box Creek (BOX) & 4 & 3.59 & 1.51 & 2.28 & 1.44 & 3.68 & $\underset{S D}{S D}$ & 4 & 1.75 & 1.03 & 2.65 & 1.54 & 2. \\
\hline St & 4 & 3.87 & 1.0 & 1.8 & 0.4 & 3.6 & $\begin{array}{l}\text { Keefer Wallace } \\
\text { (KEW) }\end{array}$ & & & & & & \\
\hline Hiawatha (HIA) & 4 & 1.93 & 1.0 & 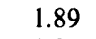 & 1. & 2.31 & $\begin{array}{c}(\mathrm{KEW}) \\
\mathrm{FL}\end{array}$ & 3 & $\begin{array}{l}1.73 \\
1.46\end{array}$ & 0.3 & $\begin{array}{l}2.49 \\
0.36\end{array}$ & $\begin{array}{l}0.32 \\
0.35\end{array}$ & $\begin{array}{l}2.47 \\
1.21\end{array}$ \\
\hline Old Frisco (FRS) & 4 & 1.57 & 0.43 & 1.20 & & 1.71 & Cedar City & 3 & & 0.39 & & & \\
\hline TL & 4 & 1.72 & 0.83 & 0.87 & 0.56 & 1.65 & Canyon (CCC) & 4 & 1.50 & 0. & 2. & 0.33 & 2.15 \\
\hline & & & & & & & $\mathrm{F}$ & A & 1.1 & 0. & 2.26 & 0.80 & 1.5 \\
\hline
\end{tabular}
'FL $=$ flat (otherwise assume an unseeded sloped spoil), $T L=$ tailings, $\mathrm{SK}=$ stockpile,
$\mathrm{SD}=$ seeded or reclaimed.

varies from site to site. The $S$ and $A$ values for various sites and treatment combinations, as given in Tables 2 through 8 , will be useful to land managers who desire to predict the probable impacts of different factors on infiltration. Those using the tables a re urged to consult original reference sources. Where coefficients are derived from future sampling (and researchers are encouraged to do so), the coefficients should represent mean values (see Table 1) derived from individual plot data since the Philip equation may not adequately fit community data which has been lumped prior to analysis (Gifford 1976). In most instances, relatively large changes in $S$ and $A$ (i.e., 0.5 to 1.5 units) must occur before any change is deemed significant. This is largely due to the sizeable within-site heterogeniety of rangeland communities. Possible problems in sampling temporal variability of infiltration rates have been noted by Gifford (1979b).

Table 9. A $(\mathrm{cm} / \mathrm{hr})$ values in disturbed and control juniper communities. All differences are significant at the 0.10 level.

\begin{tabular}{lccc}
\hline \hline Location & Disturbed & Control & Difference \\
\hline West Huntington & 4.55 & 2.45 & -2.10 \\
Loftgreen & 4.94 & 1.76 & -3.18 \\
Indian Peaks \#4 & -.90 & 2.71 & 3.61 \\
Jockeys & 7.48 & 1.00 & -6.48 \\
USU Study Site \#2 & 1.36 & 4.12 & 2.76 \\
\hline
\end{tabular}


Where $S$ and $A$ values are known for the plant communities in a given area, corrections for season, antecedent soil moisture, and watershed management practices may be made and infiltration and runoff may be estimated. Of course, corrections for variable rainfall rates, distribution of the plant communities within the watershed, and channel routing of flow (a complex and poorly understood function of macro- and microtopography) would also have to be made. The large inherent variability of infiltration characteristics within plant communities would necessitate adequate spatial and temporal sampling with infiltrometers to ensure accurate approximations $S$ and $A$. However, the prediction of infiltration is limited to the range of time after commencement of rainfall from which $S$ and $A$ were derived.

\section{Literature Cited}

Blackburn, W.H. 1973. Infiltration rate and sediment production of selected plant communities and soils in five rangelands in Nevada. Agr. Exp. Sta., Univ. of Nevada, Reno. Final report for BLM Contract No. 14-11-0001-4632. 99 p.

Blackburn, W.H., and C.M. Skau. 1974. Infiltration rates and sediment production of selected plant communities in Nevada. J. Range Manage. 27:476-480.

Burton, T.A. 1976. An approach to the classification of Utah mine spoils and tailings based on surface hydrology and erosion. M.S. Thesis. Utah State Univ., Logan. 92 p.

Burton, T.A., G.F. Gifford, and G.E. Hart. 1978. An approach to the classification of Utah mine spoils and tailings based on surface hydrology and erosion. Environ. Geol. 2:269-278.

Dortignac, E.J. 1951. Design and operation of the Rocky Mountain infiltrometer. U.S. Forest Serv., Rocky Mt. Forest and Range Exp. Sta. Pap. \#5. $68 \mathrm{p}$.

Fitzgerald, P.D., G.G. Cossens, and D.S. Richard. 1971. Infiltration and soil physical properties. J. Hydrology 10(2):120-126.

Gifford, G.F. 1968. Influence of various rangeland cultural treatments on runoff and sediment production from the big sage type, Eastgate Basin, Nevada. Ph.D. Diss., Utah State Univ., Logan. 138 p.

Gifford, G.F. 1976. Applicability of some infiltration formulae to rangeland infiltrometer data. J. Hydrology 28:1-11.

Gifford, G.F. 1977. Unpublished infiltrometer data.

Gifford, G.F. 1978. Use of infiltration equation coefficients as an aid in defining hydrologic impacts of range management schemes. J. Range Manage. 31:115-117.

Gifford, G.F. 1979a. Infiltrometer studies in rangeland plant communities of the Northern Territory. Aust. Rangeland J. 1:142-149.

Gifford, G.F. 1979b. Infiltration dynamics under various rangeland treatments on uniform sandy-loam soils in southeastern Utah. J. Hydrol. 42:179-185.
Gifford, G.F., and F.E. Busby. 1974. Intensive infiltrometer studies on a plowed big sagebrush site. J. Hydrology 21:81-90.

Gifford, G.F., and C.M. Skau. 1967. Influence of various rangeland cultural treatments on runoff and sediment production in the big sage type, Eastgate Basin, Nevada. Proc. Third Amer. Water Resour. Conf., San Francisco, Nov. 8-10, 1967:137-148.

Gifford, G.F., G. Williams, and G.B. Coltharp. 1970. Infiltration and erosion studies on pinyon-juniper conversion sites in southern Utah. J. Range Manage. 23:402-406.

Hanks, R.J., and G.L. Ashcroft. 1976. Physical properties of soils. Dept. of Soil Science and Biomet., Utah State Univ., Logan. 127 p.

Jaynes, R.A., and G.F. Gifford. 1977. The Philip equation: A feasible model for infiltration estimation on small rangeland watersheds? Completion Rep., Proj. JRN-22-1, Utah Water Res. Lab., Utah State Univ., Logan: 149 p.

Kirkham, D., and W.L. Powers. 1972. Advanced Soil Physics. John Wiley and Sons, Inc. $534 \mathrm{p}$.

Malekuti, A., and G.F. Gifford. 1977. Impact of plants as a source of diffuse, salt within the Colorado River Basin. Water Res. Bull 14:195-205.

Meeuwig, R.0. 1971b. Infiltration and water repellency in granitic soils. U.S. Forest Serv. Res. Pap. INT-111. 20 p.

Nhaji, S., T.W. Sammis, and D.D. Evans. 1975. Variability of infiltration characteristics and water yield of a semi-arid catchment. In: Hydrol. and Water Resour. in Ariz. and the Southwest, Vol. 5:67-77.

Philip, J.R. 1957a. The theory of infiltration: 3. moisture profiles and relation to experiment. Soil Sci. 84:163-178.

Philip, J.R. 1957b. The theory of infiltration: 4 . sorptivity and algebraic infiltration equations. Soil Sci. 84:257-264.

Philip, J.R. 1957c. The theory of infiltration: 5 . the influence of the initial moisture content. Soil Sci. 84:329-339.

Philip, J.R. 1969. Theory of infiltration. p. 215-296. In: Ven Te Chow (ed.). Advances in Hydroscience, 5.

Talsma, T. 1976. Water movement: infiltration, redistribution, and groundwater movement. Proc. Fifth Workshop of U.S./Australia Rangelands Panel, Boise, Idaho: 73-82.

Taylor, S.A., and G.L. Ashcroft. 1972. Physical Edaphology. W.H. Freeman and Company, San Francisco. 533 p.

Thompson, K.M. 1977. Unpublished infiltrometer data.

Tisdall, A.L. 1951. Antecedent soils moisture and its relation to infiltration. Aust. J. Agr. Res. 2:342-348.

U.S. Department of Agriculture. 1963. National engineering handbook, Section 4, Hydrology. U.S.G.P.O., Washington.

Williams, G. 1969. Analysis of hydrologic, edaphic, and vegetative factors affecting infiltration and erosion on certain treated and untreated pinyon-juniper sites. Ph.D. Diss., Utah State Univ. Logan. 162 p.

Williams, G., G.F. Gifford, and G.B. Coltharp. 1969. Infiltrometer studies on treated vs. untreated pinyon-juniper sites in central Utah. J. Range Manage. 22:110-114. 